\title{
Perencanaan Keuangan Keluarga untuk Anggota BKM Unggul Jaya Pecangaan Kulon Jepara
}

\author{
Faiqul Hazmi ${ }^{1}$, Ahmad Fauzan Mubarok ${ }^{2}$ \\ 1,2 Universitas Islam Nahdlatul Ulama Jepara
}

\begin{tabular}{|c|c|}
\hline Article History & ABSTRACT \\
\hline $\begin{array}{l}\text { Received } 12.04 .2019 \\
\text { Received in revised form } \\
28.07 .2019 \\
\text { Accepted } 08.10 .2019 \\
\text { Available online } 28.10 .2019\end{array}$ & $\begin{array}{l}\text { FAMILY FINANCIAL PLANNING FOR MEMBERS OF BKM UNGGUL JAYA } \\
\text { PECANGAAN KULON, JEPARA. Community Self-Reliance Agency of Unggul } \\
\text { Jaya (BKM) is as a local non-profit institution. The members are the citizen of } \\
\text { Pecangaan Kulon. The management and the staff are grouped voluntarily. The } \\
\text { program of the community self-reliance agency is financial services for micro } \\
\text { business group. The positive impacts of the program are (1) increasing } \\
\text { community welfare; (2) increasing job opportunities from villagers. However, } \\
\text { social dynamics leave problems such as the diversion of loan objectives is not in } \\
\text { accordance with the average business application of businesses to non-businesses } \\
\text { such as school funding, household purchases, house improvement, jewelry, } \\
\text { entertainment, etc. It causes negative impacts such as (1) additional debt for } \\
\text { members; (2) the changing of food consumption to debt payments; (3) bad loans } \\
\text { so that funds cannot be handed over to other members; (4) the increased debt of } \\
\text { the member to other institutions so that it makes getting worse for the finance; (5) } \\
\text { the conflict of payment in a group; (6) the environmental development programs } \\
\text { have stalled due to insufficient funding participation because members do not } \\
\text { have good financial planning; ( } 7 \text { ) the environmental services and finance } \\
\text { programs will be terminated by BKM to the environment which has arrears in } \\
\text { installments. The solutions provided in the service program are (1) providing } \\
\text { skills in determining the priority scale of household needs; (2) providing financial } \\
\text { planning skills; (3) providing Financial Check-Up training; (4) providing skills in } \\
\text { making a family financial budget; (5) Assisting and monitoring participants. }\end{array}$ \\
\hline & KEYWORDS: BKM, Financial Planning, Household Budgets. \\
\hline
\end{tabular}

DOI: $10.30653 / 002.201943 .139$

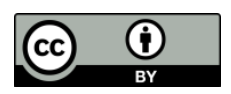

This is an open access article distributed under the terms of the Creative Commons Attribution 4.0 International License, which permits unrestricted use, distribution, and reproduction in any medium, provided the original work is properly cited. ๑) 2019 Faiqul Hazmi, Ahmad Fauzan Mubarok.

\section{PENDAHULUAN}

Badan Keswadayaan Masyarakat (BKM) sebagai institusi lokal yang dibentuk melalui program PNPM di desain sebagai institusi sukarela. Dengan demikian proses dan pembentukannya tidak banyak campur tangan pemerintah apabila dibandingkan dengan

\footnotetext{
${ }^{1}$ Corresponding author: Program Studi Perbankan Syariah, FSH Universitas Islam Nahdlatul Ulama` Jepara; Jl. Pekeng Tahunan, Jepara, Jawa Tengah; Email: faiqulhazmi@unisnu.ac.id
} 
program pemerintah yang lain, program ini lebih kental dengan nuansa pendekatan kultural (Kurnia Wijayanti, tt) merupakan salah satu institusi atau lembaga masyarakat yang berbentuk paguyuban, dengan kedudukan pimpinan secara kolektif di tingkat desa atau kelurahan, bertanggung jawab menjamin keterlibatan semua lapisan masyarakat dalam proses pengambilan keputusan secara partisipatif yang kondusif. BKM sebagai tempat berhimpun sesama warga melalui perwakilan setempat yang dipilih oleh masyarakat secara langsung melalui pemilihan dan bertumpu pada keputusan tertinggi ditangan anggota. Tujuan BKM adalah membangun modal sosial (Social Capital) dengan menumbuhkan kembali nilai-nilai kemanusiaan, ikatan-ikatan sosial dan menggalang solidaritas bersama masyarakat untuk saling bekerjasama demi kebaikan, kepentingan dan kebutuhan bersama yang akan memperkuat keswadayaan masyarakat.(Mubarak, 2010)

BKM adalah badan swadaya mandiri yang dimiliki masyarakat di tingkat lokal yang dirancang untuk dapat menjadi penggerak masyarakat agar dapat berdaya dalam mengatasi permasalahan kemiskinan. Sebagai lembaga masyarakat di tingkat lokal, BKM harus mampu memperjuangkan aspirasi dan kebutuhan semua anggota masyarakat khususnya masyarakat kurang mampu melalui local wisdom nya sendiri, agar mereka benar-benar terlibat secara aktif dan intensif dalam setiap pengambilan keputusan yang menyangkut kegiatan-kegiatan BKM, karena pada dasarnya BKM adalah pengejawantahan masyarakat lokal itu sendiri secara terorganisir.Program pemberdayaanmasyarakat yang dilakukan oleh BKM dilakukan berjangka menengah dan panjang, berkesinambungan, dan utuh.Secara nasional beberapa hasil penelitian telah membuktikan pengaruh secara signifikan kegiatan BKM terhadap (1) meningkatnya pendapatan dari penduduk desa. (2) Kesempatan kerja dari penduduk desa. (Wibowo, 2015)

Desa Pecangaan Kulon Kecamatan Pecangaan Kabupaten Jepara mempunyai BKM sejak tahun 2003 dan terus berjalan sampai saat ini portofolio Asset yang dimiliki mencapaiRp 260.997.306,- pada akhir tahun 2017. Program-Program BKM dalam bentuk pengelolaan lingkungan (UPL) dilaksanakan dalam bentuk (1)Pavingisasi; (2) Drainase; (3) Lapen; (4) Bedah Rumah, sedangkan kegiatan pelayanan keuangan dikelola oleh Unit Pelayanan Keuangan (UPK) khusus melakukan penyaluran pinjaman untuk usaha mikro. BKM membawa berbagai dampak positif diantaranya (1) Meningkatnya kesejahteraan masyarakat (2) Meningkatnya pendapatan dari penduduk desa. (3) Meningkatnya kesempatan kerja dari penduduk desa.

Potensi BKM Unggul jaya saat ini adalah: (1) Dimiliki oleh warga dan pemerintah Desa Pecangaan Kulon, Pecangaan, Jepara; (2) Kompetensi dan komitmen para anggota dibuktikan dari hasil audit tahunan, dan sustainability programsampai tahun 2018; (3) Kemampuan menampung aspirasi masyarakat dibuktikan melalui aktifnya perwakilan dari semua RT dan RW pada rembuk warga tahunan (RWT); (4) Kemampuan mengelola dana dibuktikan dengan laporan keuangan tahunan mempunyai biaya operasi yang rendah karena dikelola mandiri oleh masyarakatnya, share atau pengembalian dana surplus yang diperoleh, serta Non Performing Financing (NPF) yang terkendali. Disamping itu terdapat faktor pendukung dalam pelaksanaan program, yaitu (1) pendanaan; (2) partisipasi masyarakat yang relatif kuat di Desa Pecangaan Kulon; (3) adanya fasilitasi terus menerus dilakukan oleh fasilitator; dan (4) tersedianya buku pedoman. 
Permasalahan Mitra yang Pertama di bidang pelayanan keuangan, Pelayanan keuangan diberikan pada anggota BKM mempunyai usaha dalam bentuk fasilitas pinjaman tanpa agunan untuk digunakan menambah modal usahanya.Namun sebagian terjadi pengalihan tujuan pinjaman (Side Streaming) rata-rata dari usaha ke non usaha seperti dana sekolah, pembelian alat rumah tangga, perbaikan rumah, perhiasan, hiburan (rekreasi dsb) hal tersebut akan mengganggu usaha anggota serta dalam jangka panjang berpotensi menimbulkan dampak negatif diantaranya (1) Bertambahnya beban keuangan keluarga anggota peminjam dikarenakan bertambahnya hutang tanpa penambahan penghasilan (2) Bergesernya konsumsi prioritas menjadi konsumsi pembayaran hutang (3) Anggota penerima pinjaman menambah hutang ke lembaga lain (4) Munculnya tekanan untuk mengembalikan pinjaman tepat waktu dari anggota lainya.(5) Pinjaman mengalami kemacetan, sehingga pinjaman tidak bias bergulir ke anggota lainya (6) Konflik dalam kelompok peminjam dikarenakan problem pembayaran.

Permasalahan Kedua di bidang lingkungan dan sosial Hampir setiap kegiatan pembangunan lingkungan BKM dilakukan melalui partisipasi warga baik partisipasi tenaga maupun partisipasi dana. Dikarenakan program BKM dilakukan secara bertahap dan dalam jumlah terbatas maka masyarakat perlu mempersiapkan partisipasi dana untuk menyambut kesempatan mendapatkan manfaat program. Seringkali masyarakat tidak mendapatkan kesempatan mendapatkan program dikarenakan belum mencukupinya partisipasi dana. Dihentikanya program lingkungan pada rukun tetangga (RT) yang mempunyai tunggakan angsuran pelayanan keuangan.

Berdasarkan permasalahan di atas, maka solusi yang diberikan, pertama, memberikan pengetahuan dalam menentukan skala prioritas kebutuhan rumah tangga, perencanaan keuangan, dan alternatif penyimpanan dana atau investasi legal beserta risiko yang melekat. Kedua, memberikan pelatihan Financial Check Up. Ketiga, memberikan pelatihan membuat skala prioritas kebutuhan rumah tangga, praktik membuat anggaran dan praktik membuat target keuangan. Keempat Melakukan pendampingan dan monitoring kepada peserta. Untuk menunjang solusi tersebut, program pengabdian kepada masyarakat ini menghasilkan luaran berupa: 1) Aplikasi praktis financial check up, dan perencanaan keuangan keluarga yang bisa diakses melalui komputer atau smartphone; dan 2) Produk atau manual operasional aplikasi financial check up dan perencanaan keuangan keluarga.

\section{METODE PELAKSANAAN}

Perencanaan keuangan keluarga merupakan seni pengelolaan keuangan yang dilakukan oleh suatu keluarga untuk mencapai tujuan yang efektif, efisien, dan bermanfaat, sehingga keluarga tersebut menjadi keluarga yang sejahtera. Secara umum, aktivitas yang dilakukan adalah proses pengelolaan penghasilan untuk mencapai tujuan finansial seperti keinginan memiliki dana pernikahan, dana kelahiran anak dan lain-lain (OJK, 2013). Adapun langkah yang ditempuh dalam pengabdian ini mencakup beberapa tahap seperti pada Gambar 1. 


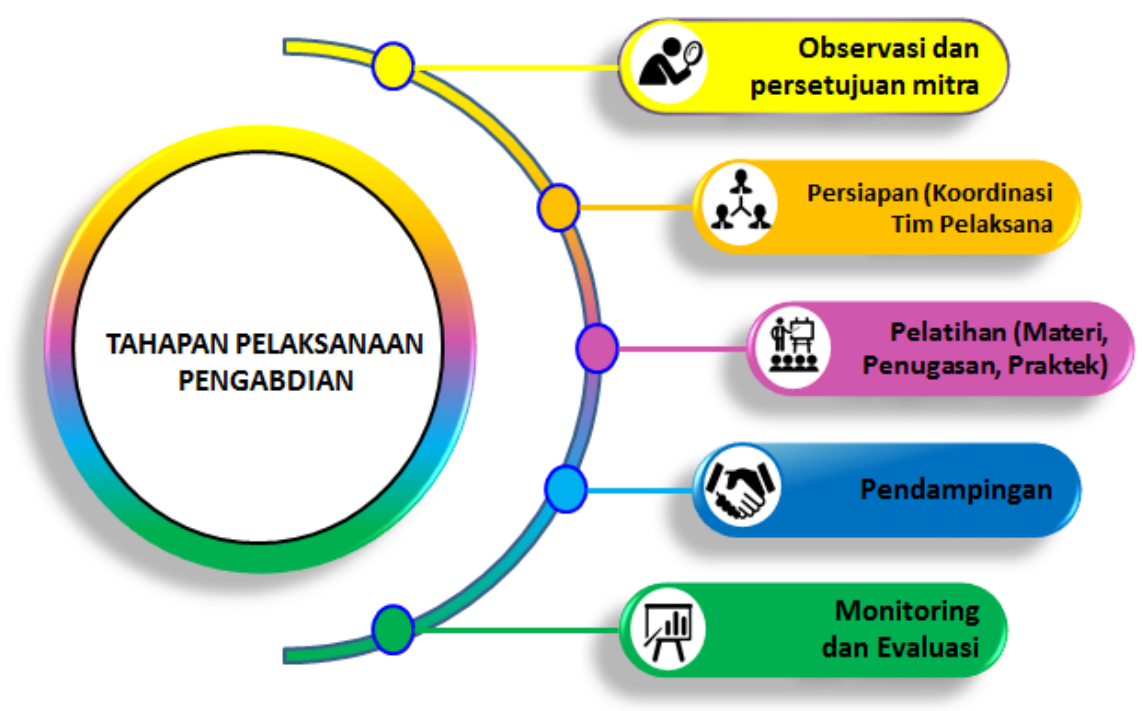

Gambar 1. Tahapan Pelaksanaan Program Pengabdian

Tahapan atau langkah-langkah pelaksanaan program pengabdian kepada masyarakat pada Gambar 1 dapat dijelaskan sebagai berikut.

1) Observasi, Mengawali kegiatan program pengabdian masyarakat dengan melakukan observasi menganalisis situasi dan potensi mitra serta meminta persetujuan dan kesediaan menjadi subyek aktif.

2) Persiapan, Pada tahapan persiapan tim pelaksana melakukan koordinasi perencanaan pelaksanaan program secara konseptual, operasional serta pembagian tugas masing-masing anggota pengabdian masyarakat, serta pembuatan instrument pengabdian masyarakat seperti lembar presensi, sertifikat pelatihan, dokumentasi, Aplikasi, alat peraga, modul financial check up, dan perencanaan keuangan keluarga.

3) Tahap Pelaksanaan Pelatihan. Pelaksanaan program merupakan tahap inti yang diberikan kepada Anggota BKM Unggul Jaya di kemas dalam bentuk workshop di aula balai desa Pecangaan Kulon J1 Raya Kudus Jepara kodepos 59462, dengan beberapa tahapan berikut: Pertama, penyajian materi perencanaan keuangan (Financial Planning) (Suwiknyo, 2009); Kedua, penugasan yang mencakup pembuatan (a) Praktik financial check up (b) praktik membuat skala prioritas (c) Praktik membuat target-target keuangan dengan mempertimbangkan inflasi (Rahmani, 2016); Ketiga, Workshop Perencanaan Keuangan Keluarga dengan desain pembelajaran sebagaimana berikut; (1) Model Pembelajaran dengan model pembelajaran kooperatif dan kolaboratif dengan tujuan peserta bisa menerima terhadap keragaman serta pengembangan keterampilan sosial; (2) Media yang digunakan, (a) Alat peraga analog (b) Aplikasi sederhana bagi yang mampu menggunakan komputer atau smartphone, (c) Modul perencanaan keuangan. Gambar 2 menjelaskan tahapan pelaksanaan pelatihan berikut. 


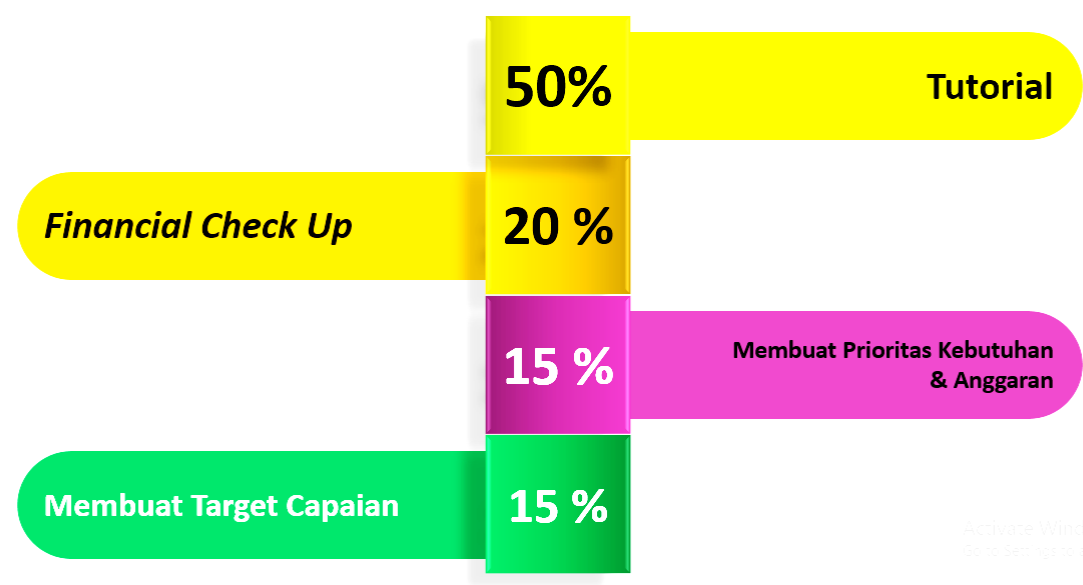

\section{Gambar 2. Tahapan Pelaksanaan Workshop}

4) Tahap Pendampingan. Tahap ini bertujuan membantu individu dan atau kelompok dalam pengembangan manusia seutuhnya (mengoptimalkan potensinya), dengan lebih spesifik adalah membantu dampingan agar mampu mandiri antara lain memiliki sumber penghasilan yang tetap dan layak, sehingga dapat menjadi warga masyarakat yang mampu berperan dalam lingkungannya. Diharapkan melalui pendampingan yang intens, kendala-kendala pelaksanaan akan dapat diatasi dengan mudah. Dalam pengabdian ini pengabdi berfungsi sebagai pendamping dari anggota koperasi mitra untuk menjadi (1) Fasilitator dengan cara memfasilitasi berbagai kegiatan untuk menunjang keberhasilan program (2) Motivator Pendamping dapat memotivasi mengajak danmempengaruhi kelompok dampingan anggota dan pengurus koperasi wanita lestari mandiri memberikaninspirasi untuk aksi nyata meningkatkan dan mendorong kesadaran untuk keberhasilan program (3) Inovator, diharapkan pendamping mampu membantu merumuskan ataumerangsang dampingan untuk melahirkan gagasanbaru dalam pengembangan usaha mensukseskan program pengabdian (4) Katalisator Pendamping dapat membantu menjembatani atau menghubungkan pengurus BKM dengan anggota anggota BKM Unggul Jaya untuk kesuksesan perencanaan keuangan. (5) Mediator yaitu dengan mempertemukan pengurus dan anggota BKM Unggul Jaya dengan pihak-pihak yang dapat menjadi mitra pendukung yaitu perbankan, koperasi,dan sebagainya. Serta menengahi (mediasi) dan berunding (negosiasi) yaitu kemampuan untuk menghadapi dan mengatasi konflik yang terjadi pada mitra pengabdian (Sodli el al, 2014)

Tahap pendampingan dilakukan pada saat workshop maupun setelah acara workshop terhadap peserta yang mengalami kesulitan dalam mengaplikasikan pengetahuanya. Instrument komunikasi dilakukan melalui berbagai media seperti aplikasi whatsapp, sms dsb. Melakukan pendampingan ke lapangan pada peserta yang telah mengikuti workshop. Pendampingan dilakukan dengan cara sampling pada beberapa peserta dan data sekunder berupa data portofolio tabungan dan pinjaman pada BKM unggul jaya. Tahapan pendampingan bertujuan untuk (a) Kegiatan tersebut dilakukan agar apa yang didapatkan pada tutorial dan latihan praktik dapat di implementasikan dalam keseharian (b) Mengatasi permasalahan 
yang muncul dalam pengimplementasian setelah workshop. indikator keberhasilanya adalah peserta dapat menjalankan secara konsisten menjalankan rencana keuangan keluarganya.

5) Monitoring dan Evaluasi. Setelah tahap pelaksanaan dan pendampingan pengabdian masyarakat ini selesai kemudian dilakukan review terhadap semua proses yang telah berlangsung untuk dilakukan evaluasi. Sehingga program tersebut dapat direplikasi di tempat lain.

\section{HASIL DAN PEMBAHASAN}

\section{Penyajian materi perencanaan keuangan (Financial Planning)}

Workshop perencanaan keuangan keluarga dilakukan pada hari selasa tanggal 1 Mei 2018, dilaksanakan pada tanggal tersebut dengan tujuan agar peserta yang diundang dapat menghadiri acara tersebut tanpa terhalang rutinitas pekerjaan dikarenakan bertepatan dengan hari libur nasional. Penyajian materi dilakukan dalam 45 menit kemudian dilanjutkan dengan penugasan-penugasan. Anggota BKM unggul jaya terdiri dari masyarakat umum dengan berbagai latar belakang usia, pendidikan dan kegiatan ekonominya masing masing. Oleh karenanya ukuran keberhasilan tutorial menggunakan metode pre test dan post test ringan berupa pertanyaan yang bersifat kognitif.

Hasil menunjukkan bahwa Kegiatan workshop pengabdian masyarakat perencanaan keuangan keluarga untuk anggota BKM Unggul Jaya Pecangaan Kulon khususnya dalam kegiatan tutorial telah meningkatkan pengetahuan (kognitif) peserta dalam hal perencanaan keuangan keluarga kesimpulan tersebut diambil dari rata-rata $24.86 \%$ kenaikan nilai pre test dengan post test. yaitu sebanyak 57 peserta mengalami peningkatan nilai dari pre test ke post test, 8 orang peserta mempunyai nilai sama antara pre dan post test dan 4 orang justru mengalami penurunan dari pre test ke post test.

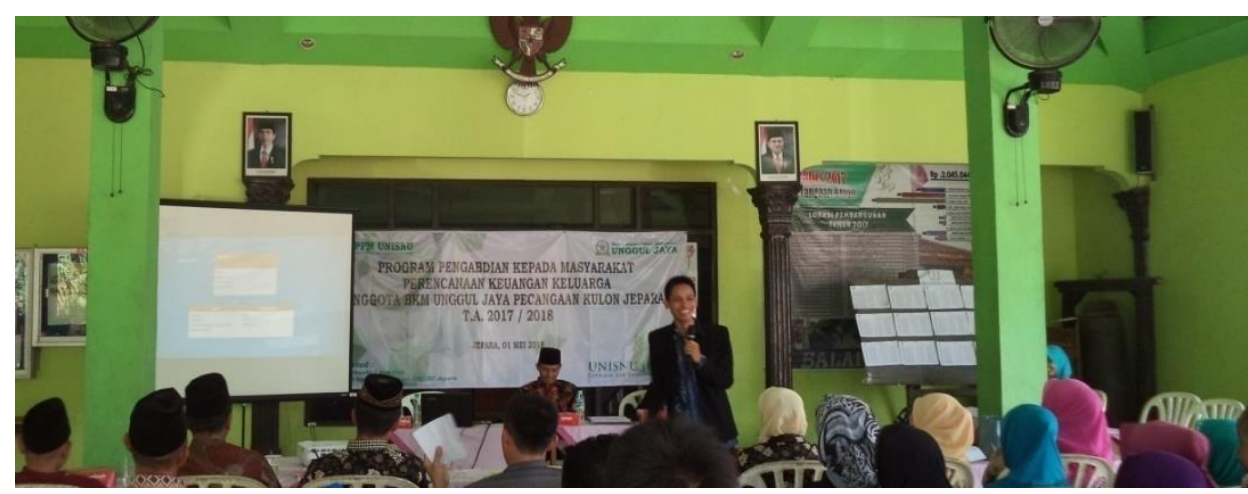

Gambar 3. Pelaksanaan Tutorial

\section{Penugasan Praktik Financial Check $U p$}

Setelah tutorial selesai peserta workshop diberi tugas untuk praktik financial check up dengan tujuan mengetahui kondisi keadaan keuangan keluarga sehingga bisa dilakukan langkah untuk memperbaiki permasalahan keuangan keluarga. Permasalahan yang banyak dialami peserta diantaranya (1) Keadaan dimana biaya rumah tangga menempati posisi tertinggi dari alokasi pengeluaran keluarga (2) Tidak mempunyai tabungan untuk 
kondisi darurat (3) Tidak mempunyai investasi yang memadai, (4) Perbandingan cicilan hutang dan pendapatan bulanan yang tidak proporsional. serta sebagian besar tidak mempunyai proteksi terhadap risiko.

\section{Penugasan Praktik Membuat Skala Prioritas}

Besar kecilnya penghasilan keluarga bukan satu-satunya penentu cukup tidaknya pemenuhan kebutuhan. Penghasilan yang kecil pun bila dikelola dengan cermat dan baik akan dapat memenuhi kebutuhan-kebutuhan yang dianggap penting oleh keluarga tersebut. Sebaliknya penghasilan yang besar belum tentu dapat memenuhi semua kebutuhan jika salah atau kurang cermat dalam mengelolanya. Skala prioritas menjadi salah satu faktor kunci keberhasilanya. Pada tahapan ini peserta dihadapkan pada berbagai kondisi dimana diharuskan memilih dari berbagai pilihan dengan keadaan keuangan masing masing. Pada tahapan praktik membuat skala prioritas peserta diarahkan untuk mampu membuat penyelesaian permasalahan yang dihadapinya serta membuat pilihan untuk mengutamakan kebutuhan-kebutuhan yang sifatnya Wajib terpenuhi terlebih dahulu kemudian kebutuhan yang bersifat Sunnah, serta yang bersifat Mubah. Peserta dikondisikan untuk mampu membuat skala prioritas kebutuhan primer (dharuriyat), sekunder (Hajjiyat) dan tersier (tahsiniyat).

\section{Penugasan Praktik Membuat Target-Target atau Rencana Keuangan}

Peserta workshop membuat rencana keuangan sesuai kebutuhan masing-masing, menuliskan berbagai kebutuhan dan keinginan yang telah diseleksi sebelumnya untuk dicapai melalui perencanaan keuangan yang baik. Untuk mencapai kebutuhan dan keinginan tersebut dibutuhkan (1) Konsistensi dalam alokasi dana, (2) Memperhatikan inflasi yang berjalan untuk mengetahui jumlah riil nilai uang pada saat rencana tersebut nantinya direalisasikan, (3) Penempatan investasi dana yang aman dengan hasil yang maksimal. Metode praktik dengan mengisi template yang telah disediakan untuk memudahkan (1) Mengetahui berapa lama realisasi dari rencana (2) Mengetahui jumlah investasi langsung, tahunan, bulanan, sampai harian yang dibutuhkan (3) Memudahkan membuat opsi perkiraan hasil investasi dan inflasi yang membuat nilai mata uang mengalami penurunan dibandingkan dengan harga barang dan jasa.

\section{Pendampingan Peserta}

Melakukan pendampingan dan monitoring ke lapangan pada peserta yang telah mengikuti workshop. Pendampingan dan monitoring dilakukan dengan cara sampling pada beberapa peserta dan data sekunder berupa data portofolio tabungan dan pinjaman pada BKM unggul jaya. Tahapan pendampingan dan Monitoring bertujuan untuk (a) Kegiatan tersebut dilakukan agar apa yang didapatkan pada tutorial dan latihan praktik dapat di implementasikan dalam keseharian (b) Mengatasi permasalahan yang muncul dalam pengimplementasian setelah workshop. indikator keberhasilanya adalah peserta dapat menjalankan secara konsisten menjalankan rencana keuangan keluarganya.

Pendampingan menurut kamus besar bahasa Indonesia adalah proses, cara, perbuatan mendampingi atau mendampingkan. Pendampingan bertujuan membantu individu dan atau kelompok dalam pengembangan manusia seutuhnya (mengoptimalkan potensinya), dengan lebih spesifik adalah membantu dampingan agar mampu mandiri antara lain memiliki sumber penghasilan yang tetap dan layak, sehingga 
dapat menjadi warga masyarakat yang mampu berperan dalam lingkungannya. Diharapkan melalui pendampingan yang intens, kendala-kendala pelaksanaan akan dapat diatasi dengan mudah.

Dalam pelaksanaan pengabdian ini, pengabdi berfungsi sebagai pendamping dari anggota koperasi mitra untuk menjadi (1) Fasilitator dengan cara memfasilitasi berbagai kegiatan untuk menunjang keberhasilan program (2) Motivator Pendamping dapat memotivasi mengajak dan mempengaruhi kelompok dampingan anggota dan pengurus koperasi wanita lestari mandiri memberikan inspirasi untuk aksi nyata meningkatkan dan mendorong kesadaran untuk keberhasilan program (3) Inovator, diharapkan pendamping mampu membantu merumuskan ataumerangsang dampingan untuk melahirkan gagasanbaru dalam pengembangan usaha mensukseskan program pengabdian (4) Katalisator Pendamping dapat membantu menjembatani atau menghubungkan pengurus BKM dengan anggota anggota BKM Unggul Jaya untuk kesuksesan perencanaan keuangan. (5) Mediator yaitu dengan mempertemukan pengurus dan anggota BKM Unggul Jaya dengan pihak-pihak yang dapat menjadi mitra pendukung yaitu perbankan, koperasi,dan sebagainya. Serta menengahi (mediasi) dan berunding (negosiasi) yaitu kemampuan untuk menghadapi dan mengatasi konflik yang terjadi pada mitra pengabdian (Sodli el al, 2014)

\section{Monitoring dan Evaluasi}

Diperlukan monitoring agar kesalahan awal dapat segera diketahui dan dapat dilakukan tindakan perbaikan, sehingga mengurangi risiko yang lebih besar. Sedangkan tujuan dari monitoring program adalah (1) Menjaga agar kebijakan yang sedang diimplementasikan yaitu perubahan pola pengelolaan keuangan yang terencana sesuai dengan tujuan dan sasaran, (2) Menemukan kesalahan sedini mungkin sehingga mengurangi risiko yang lebih besar. (3) Melakukan tindakan modifikasi terhadap kebijakan apabila hasil monitoring mengharuskan untuk itu.

Kegiatan monitoring dilakukan dengan cara (1) Metode dokumentasi dari berbagai laporan kegiatan bulanan melalui berbagai media diantaranya Whatsapp, SMS dan telepon. (2) Metode survei: tujuannya untuk menjaring data dari para peserta program perencanaan keuangan keluarga. (3) Metode observasi lapangan : untuk mengamati data empiris di lapangan dan bertujuan untuk lebih meyakinkan dalam membuat penilaian tentang proses dari kebijakan. digunakan untuk melengkapi metode survei. (4) Metode wawancara menggunakan pedoman wawancara menanyakan berbagai aspek yang berhubungan dengan perencanaan keuangan keluarga. (5) Metode FGD: dengan melakukan pertemuan dan diskusi dengan seluruh peserta program yaitu anggota BKM Unggul Jaya. Dengan cara demikian, maka berbagai informasi yang lebih valid akan dapat diperoleh melalui cross check data dan informasi dari berbagai sumber.

Kegiatan evaluasi merupakan proses penilaian pencapaian tujuan dan pengungkapan kinerja untuk memberikan umpan balik bagi peningkatan kualitas kinerja program atau kegiatan mendatang. (Triwiyanto, 2015) metode evaluasi yang digunakan adalah Participatory Design dengan cara melibatkan keseluruhan alur perancangan dan tidak hanya proses evaluasi saja.dilakukan dengan melibatkan peserta yang tidak hanya digunakan sebagai obyek sasaran tetapi juga sebagai anggota yang aktif dalam team perancangan. 
Evaluasi dilakukan untuk mengetahui efektifitas kegiatan perencanaan keuangan keluarga dalam menyelesaikan masalah yang dihadapi. Dalam melakukan evaluasi terhadap rangkaian kegiatan dan hasil pencapaianya digunakan Indikator pencapaian keberhasilan program (a) Menurunya konflik antar anggota BKM (b) Meningkatnya simpanan atau asset lainya pada anggota BKM (c) Tidak ada penghentian fasilitas BKM karena menurunya portofolio pinjaman macet.

\section{SIMPULAN}

Kegiatan pengabdian masyarakat perencanaan keuangan keluarga untuk anggota BKM Unggul Jaya Pecangaan Kulon dimaksudkan untuk menyelesaikan persoalan dalam: (1) permasalahan anggota berupa konflik dan beban keuangan anggota; (2) belum maksimalnya manfaat perguliran pinjaman kepada anggota; dan (3) adanya penghentian fasilitas dari BKM ke anggota karena adanya pinjaman macet. Ketiga masalah tersebut bersumber dari kurangnya kemampuan anggota BKM Unggul Jaya dalam melakukan perencanaan keuangan keluarga.

Kegiatan yang telah dilaksanakan yaitu: Pertama workshop perencanaan keuangan keluarga pada selasa, tanggal 1 Mei 2018 dalam meningkatkan pengetahuan masyarakat mengenai perencanaan keuangan keluarga. Kegiatan awal berupa (a) Tutorial perencanaan keuangan keluarga; (b) Praktik financial check up; (c) Praktik membuat skala prioritas; (d) praktik membuat target dan rencana keuangan. Hasil dari kegiatan pertama adalah peningkatan pengetahuan dengan indikator meningkatnya nilai pre test dengan post test meningkat rata-rata sebesar $24.86 \%$. meningkatnya keterampilan peserta berupa kemampuan praktik financial check up, membuat skala prioritas konsumsi dan membuat target dan rencana keuangan. Kedua Melakukan pendampingan dan monitoring peserta.

Latar belakang pendidikan yang sangat beragam, latar belakang strata sosial dan kegiatan ekonomi yang beragam menyebabkan daya serap terhadap materi pelatihan berbeda pula . beberapa peserta tertinggal dalam mengikuti praktik dikarenakan keterbatasan kemampuan akses perangkat elektronik berupa handphone dan laptop. Hal tersebut teratasi dengan hadirnya tutor dibantu mahasiswa untuk membantu peserta.

\section{REFERENSI}

Wijayanti, K., Sjamsudin, S., \& Rozikin, M. (2014). Upaya badan keswadayaan masyarakat (BKM) dalam pemberdayaan masyarakat (Studi di Kantor Kelurahan Tanjungrejo,Kecamatan Sukun, Kota Malang). Jurnal Administrasi Publik, 1(10), 35-40.

Mubarak, Z. (2010). Evaluasi pemberdayaan masyarakat ditinjau dari proses pengembangan kapasitas pada kegiatan pnpm mandiri perkotaan di Desa Sastrodirjan Kabupaten Pekalongan. Semarang: Undip Semarang.

OJK. (2013). Perencanaan keuangan keluarga. Jakarta: Otoritas Jasa Keuangan.

Rahmani, S. (2016). Kiat-kiat merencanakan dan mengelola keuangan keluarga secara syariah . Jakarta: Amanah Sharia. 
Sodli, U. D., Susiati, S., Mustofa, Mulyana, A., Suharti, L., \& Nurlaela, N. (2014). Model pendampingan pemasaran dan kemitraan pada program kewirausahaan berbasis pariwisata. Bandung: PP Paudni Regional I Kemendikbud.

Suwiknyo, D. (2009). Tarbiyah financial. Jogjakarta: DIVA Press.

Triwiyanto. (2015). Pelaksanaan monitoring, evaluasi, dan pelaporan untuk penilaian kinerja manajerial kepala sekolah. Cakrawala Pendidikan, 34(1), 67-77.

Wibowo, T. P. (2014). Kinerja badan keswadayaan masyarakat dalam pengelolaan dana PNPM Mandiri untuk pemberdayaan masyarakat (Studi pada BKM Artha Bhakti Adhi Guna Desa Turirejo Kecamatan Lawang Kabupaten Malang). Jurnal Administrasi Publik, 2(3), 433-439. 